\title{
A genetics pioneer focused on child health challenges
}

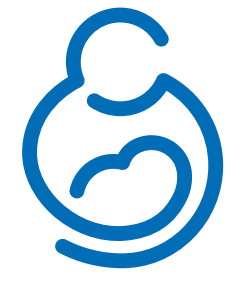

March

of Dimes

Saving babies, together
In 1938 , alarmed by decades of worsening polio epidemics, President Franklin D. Roosevelt-himself a victim of the disease-established the National Foundation for Infantile Paralysis. The agency's fundraising campaign was dubbed the "March of Dimes," playing on both the name of a popular movie newsreel feature, "The March of Time," and the radio appeals asking every American to contribute a dime (ten-cent piece) to fight polio. The campaign proved so successful that eventually the entire organization adopted the name of its fundraising phenomenon.

By 1959, after supporting the development of effective polio vaccines, the March of Dimes had helped to effect a dramatic decline in polio rates. "The foundation became the gold standard for philanthropies devoted to eliminating diseases," noted The New York Times. The organization then shifted its mission to improving the health of babies by preventing birth defects and infant mortality. But before and after this change, the organization provided seed money for major contributions to every aspect of genetic science. “The Foundation's early willingness to gamble its energies and resources to spearhead the burgeoning advance of genetics profoundly influenced the course and direction as well as the pace of advance in the entire field," said Victor McKusick, M.D., the dean of medical genetics in the United States.

A concrete example was a five-year basic genetics grant awarded in 1947 to support the work of Max Delbrück, PhD., who brought the fresh outlook of the physicist to virology — specifically, bacteriophage research. Delbrück and his colleagues who shared the 1969 Nobel Prize in Physiology or Medicine proved once and for all that nucleic acid molecules embody the genetic code, and pointed the way to understanding gene expression mechanisms in the development and function of tissues and organs.

In 1950, the March of Dimes awarded a modest fellowship to 22-year-old bacteriophage researcher, James Watson, PhD. Two years of tedious effort, interrupted by bouts of brainstorming at Cambridge University with Francis Crick PhD, revealed the double helix structure of DNA. The classic Watson-Crick paper published in Nature in 1953 credited the March of Dimes for its support.

In the years that followed, the March of Dimes played the role of both catalyst and convener. The organization sponsored the 1971 Paris Conference at which geneticists created what became known as "the Paris nomenclature" for normal and abnormal karyotypes. Beginning in 1973, the March of Dimes supported a series of international conferences on human gene mapping held in New Haven, Rotterdam, Baltimore, Winnipeg, Edinburgh and Oslo, and the published results were widely disseminated. During the 1970s and 1980s, the March of Dimes also supported numerous individual gene-mapping projects.

As the pace of genetic research quickened, investigators supported by the March of Dimes grantees developed novel methods to detect and diagnose genetic disease. For example, Yuet Wai Kan, M.D., working on a March of Dimes grant, was the first to make diagnostic use of restriction fragment length polymorphisms by using an RFLP for prenatal diagnosis of sickle cell disease.

March of Dimes grantees also took giant strides in the identification of genes responsible for specific diseases. For example, in 1991, Stephen Warren, $\mathrm{PhD}$, (initially funded by a March of Dimes 'starter' grant) and colleagues were the first to identify the long-sought genetic abnormality responsible for fragile $\mathrm{X}$ syndrome, as well as the affected protein. A milestone in gene expression came from a more recent (1996-1998) March of Dimes starter grantee, Craig Mello, PhD, who with Andrew Fire, $\mathrm{PhD}$, discovered that short segments of double-stranded RNA are potent gene-specific suppressors of gene expression. This ; phenomenon is a natural mechanism of gene regulation and is a powerful tool for study of gene function because it enables temporary 'knockdown' of genes at selected times during development. It may also become a means of therapeutic intervention.

Today the March of Dimes is funding approximately \$30 million in research annually, helping to support some 500 scientists in the United States, Canada and 14 other countries. Half a century after making its first visionary grants in genetics, the March of Dimes is still a pioneer in genetic research to save the lives and the health of babies and children.

Much of the March of Dimes research program supports developmental neurobiology, with the goal of determining how to treat disabilities such as autism, mental retardation, and specific learning and language impairments. Investigations range from delineation of normal development to molecular and cellular abnormalities underlying autism spectrum disorders (such as the fragile X, Rett and Joubert syndromes), cognitive and communicative elements of the Angelman and Williams syndromes, and perinatal brain injury in preterm infants.

A global health report from the March of Dimes published this year provides a detailed worldwide database of rates of infant death and disability from birth defects, and offers recommendations for cost-effective care and prevention measures for middle- and low-income countries.

\section{CONTACT DETAILS}

Michael Katz, M.D. Senior Vice President for Research and Global Programs March of Dimes, 1275 Mamaroneck Avenue, White Plains, New York 10605

e-mail: mkatz@marchofdimes.com 